\title{
Determination of heat of evaporation of soy-carrot mixture
}

\author{
Zhanna Petrova, Natalia Dmytrenko, Kateryna Slobodianiuk \\ Department of Heat and Mass - Transfer in Heat - Engineering, Institute of Engineering \\ Thermophysics National academy of Sciences of Ukraine, UKRAINE, Kyiv, Bulahovsky Street, 2 , E-mail: \\ bergelzhanna@ukr.net
}

Thermal effect - one of the most widespread heat-engineering operations in the processes of processing of plant raw materials. in the process of drying vegetable raw materials a lot of energy is spent on the evaporation of moisture. The practice of drying a series of complex plant materials indicates a significant difference in the actual values of heat consumption to evaporate from them the moisture from the heat of evaporation of pure water.

Keywords - specific heat of evaporation, moisture, heat-transfer, mass-transfer, drying.

\section{Introduction}

The main problem of drying whole soybeans is maximal preservation of phytoestrogens and prevention of oxidation of its lipids [1,2]. Growth of energy costs when drying vegetable materials is associated with difficult permeability of cell membranes for water and the difficulty of removing water that interacts with the soluble components of cellular juice and skeletal material of the material. Consequently, it is important to investigate the effect of creating functional compositions of plant material on the specific heat of its evaporation [3]. To determination of the heat consumption for evaporation of moisture from the proposed functional mixtures, a specific heat of evaporation of water from them and their components was investigated.

The calorimetric method was used, based on the continuous simultaneous measurement of the mass loss of the sample and the amount of heat expended on the evaporation of moisture during isothermal drying. Experiments were carried out with the help of the improved version created in IETP NAS of Ukraine synchronous thermal analysis installations DMKI-01, where a calorimetric platform with deep cylindrical cells is used that allows to investigate disperse materials [3]. For research, chopped hygrothermically processed soy, carrots, and their functional mixtures were used. Vegetable tissues were ground to approximate size $4 \times 2 \times 3 \mathrm{~mm}$. Conductive drying of samples by mass $0,3 \mathrm{~g}$ occurred in the working chamber of the calorimetric unit, at a temperature $60^{\circ} \mathrm{C}$, in conditions close to isothermal, until the equilibrium moisture samples are reached. Drying temperature $60^{\circ} \mathrm{C}$ was identified as optimal for pre-processed protein-containing feedstock, which prevents losses of biologically active substances. The mass of dry matter in the sample was determined by the method of drying inside the working chamber at $105^{\circ} \mathrm{C}$.

The actual values of the specific heat of evaporation of water from the sample were determined from the time of the establishment of the thermodynamic equilibrium inside the calorimetric chamber, using the formula:

$$
r_{i}=\frac{\int_{\tau_{i-1}}^{\tau_{i+1}} q(\tau) d \tau}{m\left(\tau_{i-1}\right)-m\left(\tau_{i+1}\right)}
$$

where ri - specific heat consumption for evaporation in time from $\tau \mathrm{i}-1$ до $\tau \mathrm{i}+1, \mathrm{~kJ} / \mathrm{kg}$;

$\tau \mathrm{i}-1$ and $\tau \mathrm{i}+1-$ the value of the current time point, sec;

$\mathrm{q}(\tau)$ - the heat flux inside the working chamber as a function of time, $\mathrm{J} / \mathrm{sec}$;

$\mathrm{m}(\tau \mathrm{i}-1)$ and $\mathrm{m}(\tau \mathrm{i}+1)$ - sample mass in moments of time $\tau \mathrm{i}-1$ and $\tau \mathrm{i}+1, \mathrm{~kg}$. 
The results of measurement are shown in Figure 1. From Figure 1, we see that at the beginning of drying, the heat of evaporation of moisture from carrots and soy-carrot mixture is approximately $4 \ldots 5 \%$ higher than the heat of evaporation of pure water. Mixing of components has led to the fact that in the process of drying, starting with a moisture content of $65 \%$, in the mixture there is an exothermic reaction, which is accompanied by an additional heat release. It can be assumed that this is the reaction of the interaction of soy fat with carrot fat-soluble carotenoids, but more accurate determination of the nature of this reaction requires additional research.

Preliminary preparation of vegetative raw materials by the method of creating functional compositions with a specially selected ratio prevents oxidation of lipids and prolong the shelf life of processed soya and carrots.

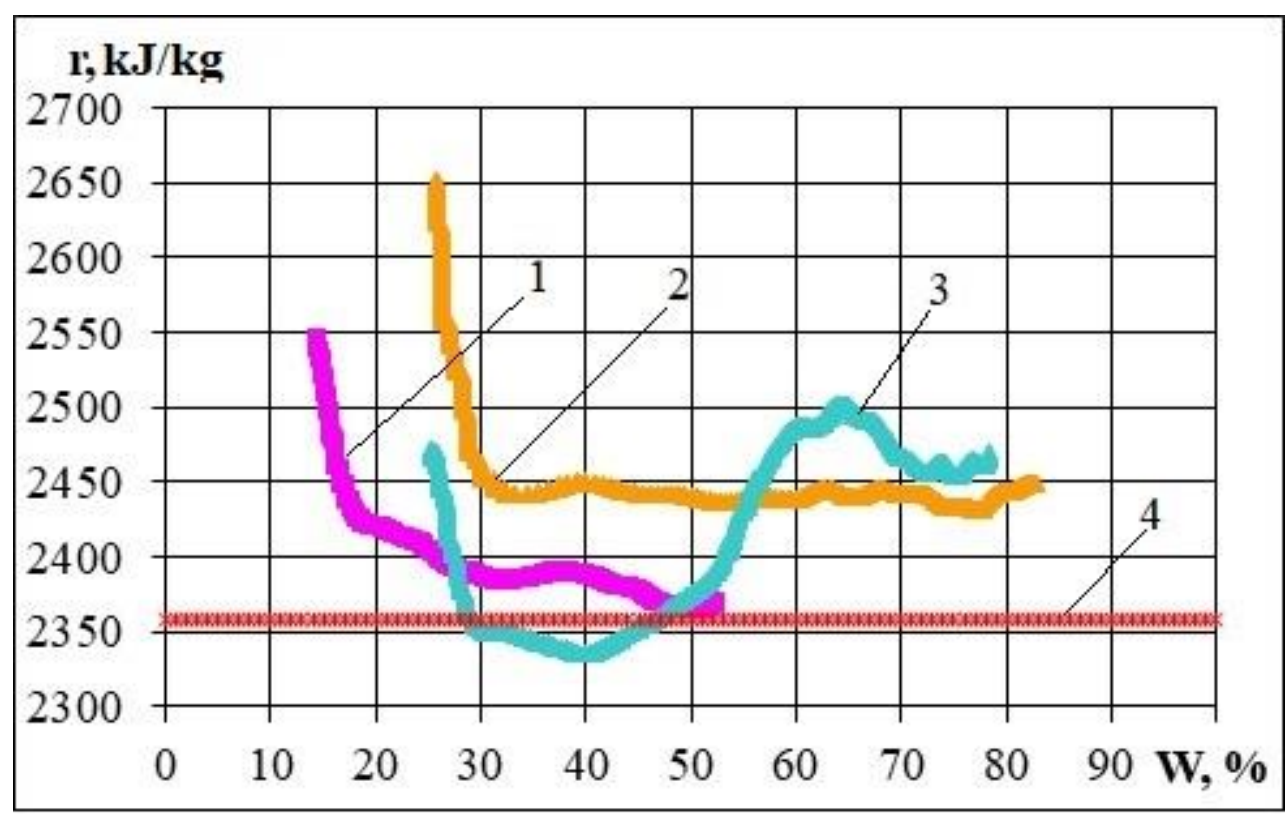

Fig.1. Dependence of the specific heat of evaporation of water from samples from there relative moisture during drying: 1 - soy, 2 - carrot, 2 - soy-carrot mixture, 4 - water.

\section{Conclusion}

It is established that specific heat expenses for evaporation of water from developed vegetable compositions based on soybean and carrot addition is smaller than it individual components. This can be explained by the fact that, when the composition of the proposed components is dried, a reaction occurs between the components of the mixture, which is accompanied by an exothermic effect. At humidity of a material from $50-30 \%$ specific expenses of heat of evaporation are lower than specific expenses of heat of evaporation of pure water. Due to the interaction of the components of the composition, the intensification of the drying process is taking place.

\section{References}

[1] Zh.O. Petrova, K.S. Slobodianiuk, "Intensyfikatsiia protsesu sushinnia roslynnoi sumishi z soi ta batatu.," ONAKhT «Naukovi pratsi», vol. 82, no. 1, September, pp. 18-22, 2018.

[2] Zh.O. Petrova, K.S. Slobodianiuk " Energy effective drying modes of soy-vegetable compositions," Ukrainian Journal of Food Science, vol. 5, no. 1, pp. 150-160, 2017.

[3] Zh.O. Petrova, N.V. Dmytrenko, K.S. Slobodianiuk “ Vyznachennia teploty vyparovuvannia soievo-shpynatnoi sumishi.," Mizhnarodna naukova internet konferentsiia «Informatsiine suspilstvo: tekhnolohichni, ekonomichni ta tekhnichni aspekty stanovlennia», Ternopil, 2018, pp. 101-103. 